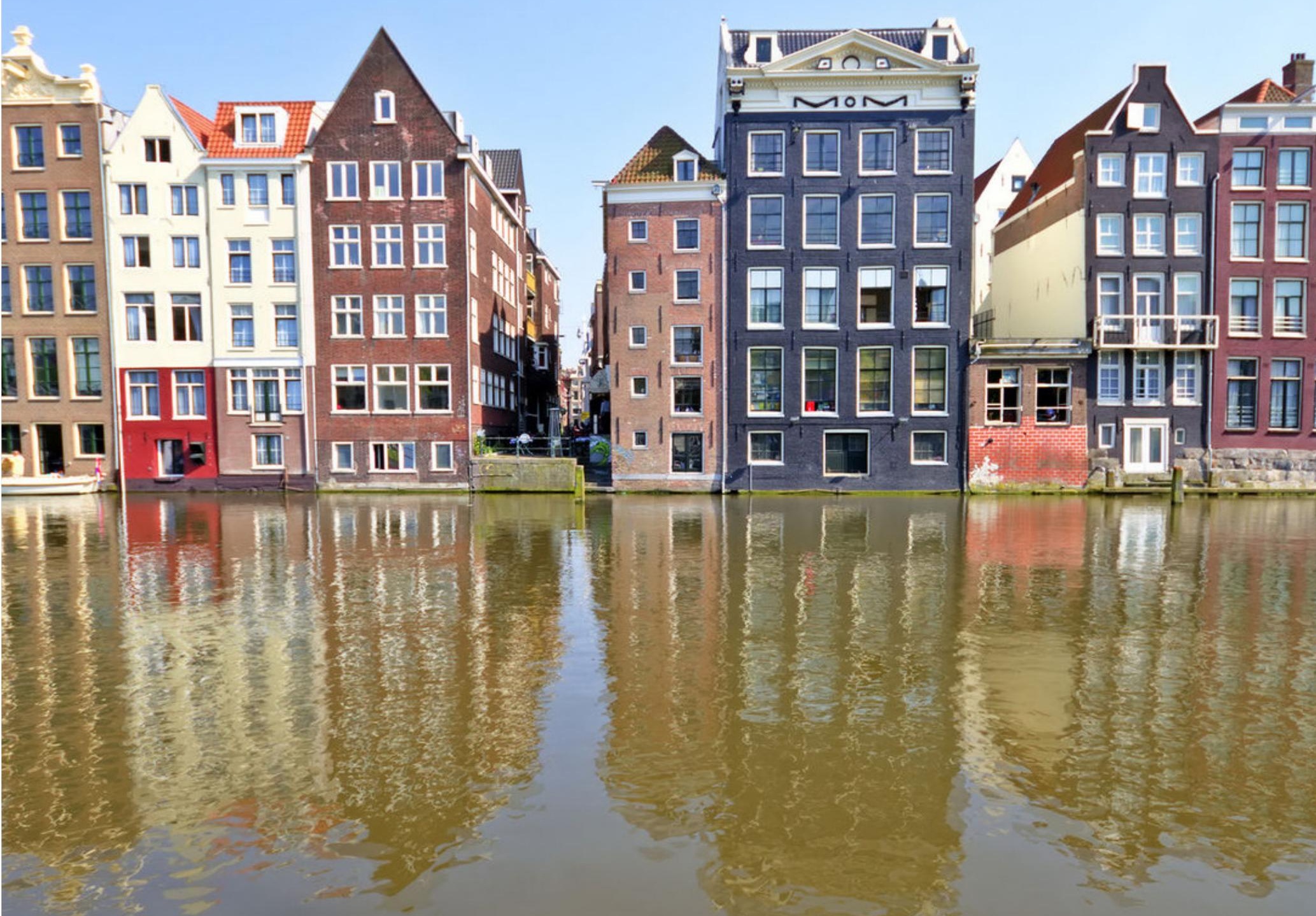

Capacities of animals to make agri-food systems more circular 



\section{Capacities of animals to make agri-food systems more circular}

Annemarie Mens $^{1}$, John Cone ${ }^{2}$, Bart van den Borne ${ }^{3}$ and Guido Bosch ${ }^{2}$

${ }^{1}$ Animal Nutrition, Wageningen Livestock Research, Wageningen University \& Research, De Elst 1, 6708 WD Wageningen

${ }^{2}$ Animal Nutrition Group, Department of Animal Sciences, Wageningen University \& Research, De Elst 1, 6708 WD Wageningen

${ }^{3}$ Quantitative Veterinary Epidemiology Group, Department of Animal Sciences, Wageningen University \& Research, Droevendaalsesteeg 1, 6708 PB Wageningen 
Mens A.J.W., J.W. Cone, B.H.P. van den Borne, G. Bosch 2021. Capacities of animals to make agri-food systems more circular. Wageningen Livestock Research, Public Report 1323.

This report can be downloaded for free at https://doi.org/10.18174/548324 or at www.wur.nl/livestockresearch (under Wageningen Livestock Research publications).

\section{(cc) BY-NC}

This work is licensed under a Creative Commons Attribution-Non Commercial 4.0 International License.

(C) Wageningen Livestock Research, part of Stichting Wageningen Research, 2021

The user may reproduce, distribute and share this work and make derivative works from it. Material by third parties which is used in the work and which are subject to intellectual property rights may not be used without prior permission from the relevant third party. The user must attribute the work by stating the name indicated by the author or licensor but may not do this in such a way as to create the impression that the author/licensor endorses the use of the work or the work of the user. The user may not use the work for commercial purposes.

Wageningen Livestock Research accepts no liability for any damage resulting from the use of the results of this study or the application of the advice contained in it.

Wageningen Livestock Research is ISO 9001:2015 certified.

All our research commissions are in line with the Terms and Conditions of the Animal Sciences Group. These are filed with the District Court of Zwolle.

Public Wageningen Livestock Research Report 1323 


\section{Contents}

$\begin{array}{lr}\text { Preface } & 5 \\ \end{array}$

$\begin{array}{lr}\text { Summary } & 7 \\ \end{array}$

1

$\begin{array}{ll}\text { Introduction } & 9\end{array}$

2

$\begin{array}{ll}\text { Animal nutrition in a nutshell } & \mathbf{1 0}\end{array}$

$\begin{array}{lll}2.1 & \text { Animal digestive capacities } & 10\end{array}$

$\begin{array}{lll}2.2 & \text { Animal nutrient requirements and tolerances } & 10\end{array}$

2.2.1 Production animals $\quad 11$

2.2.2 Non-production animals 13

2.2.3 Tolerances in animals $\quad 14$

2.2.4 Summarising notes on dietary requirements $\quad 14$

$\begin{array}{lll}2.3 & \text { Animal diets and feedstuffs } & 14\end{array}$

2.3.1 Feedstuffs 14

2.3.2 Diets 15

$3 \quad$ Upcycling in animal nutrition $\quad 17$

$\begin{array}{lll}3.1 & \text { Upcycling co-products and food leftovers } & 17\end{array}$

3.2 Animals in circular food systems in the Amsterdam Metropolitan Area 18

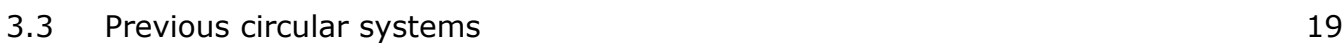

3.3.1 Production animals $\quad 19$

3.3.2 Non-production animals 20

4

Literature 



\section{Preface}

This report is a deliverable of work package 3 (WP3) within the AMS Flagship project - "Circularity by Design". Within the Flagship project a (re)design process based on circularity will be applied within the Amsterdam Metropolitan Area (AMA) with the aim to create a sustainable agri-food system. Various tools will be developed and tested within Living Labs to achieve high-end re-use of food and residual (organic) flows. The project is a collaboration between the AMS Institute and 12 different scientific disciplines of Wageningen University \& Research and is joined by various local Amsterdam-based partners. Within WP3 we aim to enhance the circularity of AMA by evaluating the potential application of food leftover streams or by-products as feed for animals. The research described in this report was conducted independently. The report is intended for the colleagues and partners involved in the project and in other WUR-flagships but might also be relevant for others with an interest in advancing circular agrifood systems and the role animals can have therein. This report is a combination of milestones and deliverables from WP3 including: an inventory of past and current AMA circular systems and initiatives with animals, an overview of the current livestock and estimation of non-production animals in the AMA, a summary of the role of animals in circular agri-food systems and a short description of feeding requirements of animals. The information represented in this report will be used to design an assessment for organic flows (waste streams/co-products), which eventually will be used to assess the AMA organic streams as feedstuffs. The assessments will be reported in a separate deliverable (planned for December 2022).

WP3 team

Annemarie Mens MSc, dr. John Cone, dr. Bart van den Borne, dr. Guido Bosch 



\section{Summary}

Animals can make food systems more circular. Livestock animals can convert (by-)products from the food system that are inedible for humans into valuable food, manure and other ecosystem services. Metropolitan areas like Amsterdam have a variability of food products that might be valuable to support feeding both productive and non-productive animals. Animal species differ in their requirements for energy and nutrients for maintenance processes and that for the production of i.e. growth, meat, milk or eggs requires additional energy and nutrients. When formulating a diet, the physical properties (to support proper gastrointestinal functioning) and the tolerance of compounds are important. Research has resulted in feeding guidelines that take these aspects into account, which are available for animals at maintenance and in production. These guidelines provide a basis to formulate or evaluate diets composed out of food leftovers and co-products and estimate animal production rates. Besides the species requirements, when formulating a diet also the purpose of the animal must be considered. Production animals are typically fed very close to their requirements whereas non-production animals are commonly fed diets that should prevent any case of deficiency. For livestock species, the feeding values of a large variety of feedstuffs has been characterised. Databases such as the one of the CVB that list these properties of feedstuffs are freely available and form the basis of the formulation of diets for livestock to attain specific production levels. It should be realized that not only single feedstuffs, but the complete composition of the diet is important.

A variety of animals is living in the Amsterdam Metropolitan Area: production animals such as ruminants, pigs and poultry, but also non-productive animals such as pets and zoo-animals. Also, non-productive animals can play a role in more circular food and feed systems since co-products and food leftovers can also be used in their feed. As animal species greatly vary in their digestive capacities and dietary requirements, incorporating (production) animal species in the design will have consequences for utilization options for a by-product and, hence, the overall circular design. As such some products may be more suitable for one (group of) animal species, whereas other products are more effectively converted by other animal species (such as insects). Other products might require first a processing technology before they can be used as a feedstuff. When designing circular agri-food systems, these aspects require consideration. 


\section{Introduction}

Urbanization resulting from a rapid increase in the human population has resulted in increased densification of urban areas. This leads to estimations that in 2050 , around $75 \%$ of the global population will live in cities. The increasing need for agri-food resources has resulted in an unsustainable use of natural resources that is exceeding planetary boundaries (loss of biosphere integrity; disruption of the nitrogen cycle) or approaching these boundaries (climate change, land use change, disruption of the phosphorus cycle) (Steffen et al., 2015). Production animals can make a food system more circular by converting food leftovers (i.e. processing by-products and waste) that are inedible for humans into valuable food, manure and other ecosystem services (Van Zanten, Van Ittersum, \& De Boer, 2019). The Amsterdam Metropolitan Area (AMA) represents a need for agri-food resources to feed its populations and produces a variety of food not consumed by humans (by-products/left-over/discards) at the same time. Finding ways to upcycle these food leftovers in local animal production in the form of animal protein (such as meat, eggs, or milk) has the potential to make the AMA agri-food system more circular. Furthermore, pet animals in the AMA do not have the capacity to upcycle food leftovers but also require food. To limit the environmental footprint of these pet animals it is of interest to explore the possibility of feeding specific leftovers and co-products. The aim of this report is to describe the role of animals in circular agri-food systems. We provide basic principles on animal characteristics that may underlie their capacities to utilise and, in the case of production animals, upcycle specific types of co-products and food leftovers. In a later stage of the project, we evaluate scenarios and safety aspects in which coproducts and food leftovers in the AMA are considered as feedstuffs in diets for production and nonproduction animals, which would make the AMA agri-food system more circular. 


\section{$2 \quad$ Animal nutrition in a nutshell}

\subsection{Animal digestive capacities}

Food sources vary greatly in physical and chemical properties, which has resulted in the evolution of specific capabilities to liberate and absorb nutrients. Food sources are composed of the macronutrients proteins, lipids and carbohydrates, and of minerals, trace elements and vitamins. The carbohydrates can be further divided into sugars, starches and fibres (non-starch polysaccharides) like, cellulose, hemicellulose and pectin. Plant cell walls may also contain lignin, which largely contributes to the strength of these walls. Also, other components may be present in small quantities, such as nucleotides, toxins, anti-nutritional factors, plant secondary metabolites, contaminants or foreign materials.

Animals differ widely in their digestive capacities and this characteristic largely determines if and how efficient an animal can liberate and absorb nutrients from a food source (for schematic overview, see Stevens \& Hume, 1998). The digestive systems that are capable of utilising plant matter, like grass, are generally complex and voluminous, as opposed to the digestive system of omnivorous and carnivorous animals. In general, animals produce enzymes to digest starches, proteins and lipids. The derived glucose (from starches), amino acids (proteins) and fatty acids (lipids) can be absorbed in the small intestine and used as energy source, to maintain or build body tissues and products or stored as energy source (glycogen, lipid). The fibrous cell walls of plants are not digested by enzymes from the animal but degraded by enzymes from the microbiota residing in specific voluminous segments of the gut. This process of microbial fermentation is less efficient than digestion with endogenous enzymes. When fibres are fermented, volatile fatty acids are produced and taken up by the host animal. These fatty acids are used as source of energy.

Ruminants, like cattle, sheep and goats, have developed a rumen before the stomach, whereas horses and rabbits have an enlarged caecum and colon to increase the utilisation of plant matter. Carnivores like cats and dogs, however, have evolved on relatively easily digestible prey animals and as such have simple and short guts with little capacity to utilise fibrous plant matter. Species that consume both plant and animal matter like pigs, chickens and humans have guts with intermediate capacities. Fish and insects can also be herbivorous, omnivorous or carnivorous in nature and as such have adapted their digestive capacities. Various insect species, like black soldier fly larvae, are detrivorous, i.e. thriving on decomposing plant and animal matter, as well as faeces. Though all these animals produce enzymes that degrade starches, proteins and lipids, the amounts and activity differ, as well as the time available for their digestive actions. As a result, the digestive capacities for extracting nutrients from resources can differ greatly among species.

\subsection{Animal nutrient requirements and tolerances}

The dietary nutrients extracted by the digestive system can be used by the animal. All animals need specific essential nutrients (water, essential amino acids, essential fatty acids, vitamins, and minerals). Essential and non-essential amino acids and fatty acids as well as monosaccharides can be used as energy sources. The nutrients and energy are used for so-called maintenance processes and production processes. 'Maintenance' is defined as the state of an animal in which its body composition remains constant. In this state there is no yield of any body tissue or product such as milk. Not meeting the nutrient requirements for maintenance can impair animal health in various ways and degrees, depending on the specific nutrient and duration of nutrient deficiency. 'Production' includes synthesis of body tissues for growth (e.g. bones, muscles, organs) or products involved in reproduction (e.g. foetuses, milk, eggs). For a non-growing and non-producing animal, the total nutrient requirement equals that for the maintenance of the body. A producing animal or an animal in growth will only produce or gain body weight if the nutrient intake exceeds the requirement for maintenance. Nutrient requirements for maintenance and production are dependent on factors, such as environment-related factors (e.g. temperature) and animal-related factors (e.g. genetic potential).

There are different classes of essential nutrients (Table 1). These essential nutrients cannot be synthesised by the animal in sufficient amounts and as such should be included in the diet or provided 
by microbiota in the gastrointestinal tract. There are some differences among animal species. For example, in cats, the metabolic capacity to synthesise taurine from cysteine and arachidonic acid from linoleic acid is insufficient. Taurine and arachidonic acid should therefore be provided via diets for cats. The amounts of nutrients and energy required for maintenance and production can differ considerably among animals due to variations in metabolism and the specific 'products' for which these are used (companion, body tissues, milk, foetuses, eggs, labour).

\section{Table $1 \quad$ Nutrients that are in general essential for animals.}

\begin{tabular}{ll} 
Class & $\begin{array}{l}\text { Nutrients } \\
\text { Amino acids }\end{array}$ \\
$\begin{array}{ll}\text { Arginine, histidine, isoleucine, leucine, lysine, methionine, phenylalanine, threonine, } \\
\text { tryptophan, valine }\end{array}$ \\
\hline Fatty acids & Linoleic acid, alpha-linolenic acid \\
\hline Vitamins - fat soluble & A, D, E, K \\
\hline Vitamins - water & B1 (thiamine), B2 (riboflavin), B3 (niacin), B5 (pantothenic acid), B6 (pyridoxine), \\
soluble & B7 (biotin), B9 (folic acid), B12 (cyanocobalamin), choline \\
\hline Minerals & Calcium, phosphorus, potassium, sodium, chloride, magnesium \\
\hline Trace elements & Copper, iodine, iron, manganese, selenium, zinc
\end{tabular}

Apart from requirements of dietary essential nutrients, some of the minerals and trace elements also need to be present in specific ratios. To ensure, for example, the acid-base balance in blood, the animal requires diets with a specific electrolyte balance (pigs, poultry) or cation-anion difference (ruminants). As copper and zinc are antagonistic with one reducing the absorption of the other, the levels and ratio between these two trace elements should be considered to prevent deficiencies. Furthermore, animals also require a diet that has specific physical properties for proper functioning of the gut. For example, coarseness of particles in the diet of pigs prevents gastric ulcer formation and as such assures health and in poultry coarse diets are essential for proper functioning of the gizzard and, as a result, overall efficient digestion of the diet.

The requirements throughout the stages of life of both livestock animals and common companion animals (e.g. dogs and cats) are well-known and extensive feeding guidelines have been developed. The requirements for specific productivity levels of livestock animals can also be computed (see e.g. Van Hall et al., 2019). For other animals, like specific insects and animals kept in zoos, nutrient and energy requirements are mostly not known, due to lack of research. The following sections provide basic knowledge on specific dietary requirements, i.e. nutritional and physical, for production and common non-production animals.

\subsubsection{Production animals}

The Centraal Veevoeder Bureau (CVB) aims to establish science-based energy and nutrient requirements, as well as to evaluate feedstuffs for terrestrial production animals in the Netherlands. The CVB is part of the Federatie Nederlandse Diervoederketen (FND) and the activities are carried out by Wageningen Livestock Research (WLR) and the Research Institute for Agriculture, Fisheries and Food (ILVO, Ghent, Belgium). The requirements of production animals are well documented and booklets (Dutch Feed Evaluation Table) with feeding guidelines are available for cattle, sheep and goats (CVB, 2016), pigs (CVB, 2020) and poultry (CVB, 2018). Worldwide, there are different institutes that produce similar tables (e.g. SFR, NRC, INRAE-CIRAD-AFZ). For aqua cultural fish similar knowledge has been developed and translated into nutritional guidelines, but these are not considered in this report.

The requirements of energy and nitrogen (protein) depend on several factors related to the animal, such as breed, age, gender, bodyweight, activity, health status, physiological status (lactating or not), parity, days in milk, milk yield, and milk composition. Environmental factors, such as space, climate, sanitary status and social environment can also impact requirements. Equations and tables have been developed to determine the requirement of an animal and some of these are included as examples in Appendix 2. It should be noted that every equation only predicts a theoretical average for a specific group of animals, living under specific conditions. 
Requirements of dairy cows, sheep and goats

The energy requirements of dairy cows, sheep and goats is expressed in so-called feed unit milk (VEM = 'voeder-eenheid melk'). The amount of VEM per day for maintenance and milk production is based on body weight of the animal plus the amount of milk it produces. Milk is corrected for fat content in the milk or for both fat and protein content in milk (FPCM).

Apart from energy, ruminants also require essential amino acids. The microbiota in the rumen utilise amino acids from the feed proteins, but also synthesise amino acids de novo. The amino acids are incorporated in microbial proteins. To meet the essential amino acid requirements, ruminants rely on these microbial proteins. As such, it is important to assure a proper functioning of the rumen. The amount of intestinal digestible protein (DVE = 'darm verteerbaar eiwit') a ruminant requires for maintenance is based on the body weight. The amount of DVE required for milk production is based on the milk protein production.

Ruminants cannot survive on only fast fermentable starch, protein and other fast fermentable components. They should also be fed with slowly fermentable fibres, such as maize stover (stalks and leaves), low quality grass or hay or cereal straw. In the rumen, feed is fermented by the rumen microbiota (bacteria, protozoa, fungi) and there should be a fibre layer to hold the microbiota. If such a layer is not present in the rumen, rumen fluid with the microbiota will pass too fast to the abomasum and not enough volatile fatty acids will be produced in the rumen. This will result in a starving animal. The Dutch Feed Evaluation Table (CVB, 2010) gives a value for the structure of each feed component. The structure value (SV) of a ration should be at least 1.0. Fast fermentable feedstuffs or ingredients, such as young grass or maize gluten feed have a low SV value and poorly fermentable feedstuffs have a high SV value, also based on their physical structure, such as particle size.

The CVB table gives the requirements of 14 different minerals for 4 categories of dairy cattle; 8 to 3 weeks before parturition, 3 to 0 weeks before parturition, cows producing $20 \mathrm{~kg}$ milk per day and producing $40 \mathrm{~kg}$ milk per day. The main minerals are copper, zinc, manganese and iron. CVB only gives the requirements of vitamins $A$ and $D$. The requirement of vitamin $A$ depends on the daily milk yield $(\mathrm{kg})$ while that of vitamin $D$ depends on the weight $(\mathrm{kg})$ of the animal. The formula to calculate the daily requirement of vitamin $A$ equals $24.000+1500 *$ milk yield, expressed in international units (IU). The formula to calculate the daily requirement of vitamin $D$ equals $10 *$ body weight, also expressed in IU.

\section{Requirements of pigs}

Growing pigs are used for meat production. To synthesise body tissues from weaning to slaughter, a pig requires energy, amino acids, calcium, phosphorus, trace minerals and vitamins above the requirements of these nutrients for maintenance. The energy requirements are based on the weight gain according to the target growth curves for boars, barrows (i.e. castrated boars) and gilts of a specific breed. Feeding tables, such as the CVB (2020), specify the requirements for all nutrients, with special focus on essential amino acids, phosphorus and calcium. The amino acid requirements are based on the so-called 'first limiting essential amino acid' (i.e. the essential amino acid that first become deficient in a diet), which is generally lysine. All other requirements of essential amino acids are estimated as a ratio of the lysine requirements. The amino acid requirements are estimated to optimise growth and minimise the feed conversion ratio ( $\mathrm{kg}$ feed needed per $\mathrm{kg}$ of body weight gain or product). Mineral and trace element requirements also depend on the growth phase of the pigs. Gestating sows require energy and nutrients for maintenance and growth of the unborn piglets, the uterus and the mammary gland. Lactating sows require additional nutrients for milk production. The requirements of sows depend on factors such as days in gestation, parity, litter size and litter growth.

\section{Requirements of poultry}

In poultry the energy requirements are expressed in metabolizable energy (OE = 'omzetbare energie' in $\mathrm{MJ} / \mathrm{kg}$ or $\mathrm{kcal} / \mathrm{kg}$ ) and can be divided into three values, based on the type of poultry: (1) OEpl for adult, non-laying poultry, (2) OElh for laying hens ('leghennen') and (3) OEvlk for broilers ('vleeskuikens'). The OEvlk is often also used for growing poultry such as turkeys, ducks and rearing hens. The OEIh and OEvlk are calculated differently since the production goals differ. In broilers the focus is on growth and energy requirements are therefore calculated by maintenance and growth, while with laying hens the focus is on egg production and a more stable body weight with limited growth (calculations with maintenance, growth and production).

Requirements for all nutrients have been established, with special focus on essential amino acids, phosphorus and calcium (see CVB, 2018). Similar to pigs, the amino acid requirements are based on 
the first limiting essential amino acid lysine. All other requirements of essential amino acids are estimated as a ratio of the lysine requirements. The amino acid requirements are estimated to optimise growth and minimise the feed conversion ratio. Both broilers and layers are mostly fed by a system of phase feeding, with diets being adapted to the energy and nutrient requirements of the birds within that typical phase.

As indicated above, the physical form of the diet offered to poultry is important. It should contain coarse particles, from e.g. whole and/or broken wheat, to stimulate gizzard development and, thereby, increasing digestive efficiency. For laying hens, foraging behaviour is stimulated by supplying the diet in a mash or crumble form, which prevents abnormal behaviour, such as feather pecking.

\section{Requirements of insects}

The energy and (essential) nutrient requirements of insect species used for insect biomass production (e.g. black soldier fly larvae, yellow mealworms) have not been determined until now. Feeding guidelines are therefore also still in their infancy and largely based on internal trial-and-error studies conducted by companies. It is assumed that the essential nutrients listed in Table 1 are in general also essential for insects with some exceptions. For example, sterols are essential in insects, whereas these are nonessential in conventional livestock species. How much of these nutrients should be provided to optimise insect biomass production and resource conversion efficiency remains to be determined.

\subsubsection{Non-production animals}

The science-based energy and nutrient requirements of dogs and cats are documented by the National Research Council in the USA (NRC, 2006). The European Pet Food Industry (FEDIAF) produced nutritional guidelines for feeding dogs and cats, based on a comprehensive review of data in NRC (2006) and other existing literature. These guidelines are updated on a yearly basis and reviewed by independent veterinary nutritionists throughout Europe. FEDIAF also published nutritional guidelines for feeding pet rabbits (FEDIAF, 2013). The CVB published feeding guidelines for horses and ponies (CVB, 2016) and for rabbits (CVB, 2016). Regarding the latter, these guidelines are specifically for rabbits kept for meat production.

\section{Requirements of dogs and cats}

Dog breeds may vary extremely in size ( 1 to $90 \mathrm{~kg}$ mature body weight) but also temperament and insulation characteristics of skin and hair coat may vary. Such variability also translates into variations in energy requirements in different stages of their life. The average energy requirements of adult dogs are described by FEDIAF (2020) and are based on body weight in combination with age and a range of activity levels. Moreover, specific energy requirements are defined for obese prone adults and there are some breed-specific requirements (Great Danes, Newfoundlands). For puppies, energy requirements are also depending on body weight and phase of growth. Average energy requirements depend also on phase of gestation and, for lactating bitches, on the number of puppies. Nutrient requirements and guidelines are available for dogs at maintenance (adult) and those in early and late growth (puppies) or in reproduction (gestating or lactating bitches).

Cats show less variation in average energy requirements than dogs and as such the requirements are less differentiated. Requirements depend on body weight in combination with only two activity levels. No differentiation is made among cats differing in age classes. For kittens, three growth phases are distinguished with specific energy requirements. There is no differentiation among phases in gestation, but for lactation the average energy requirements depend on the number of kittens. Nutrient requirements and guidelines are available for cats at maintenance (adult) and those in growth (kittens) or in reproduction (gestating or lactating queens).

\section{Requirements of horses and ponies}

The energy and nutrient requirements of horses and ponies are described by the CVB (2016). The maintenance energy and protein requirements of adult horses and ponies largely depend on their body weight, but breed, sex and temperament are also taken into account. For daily intake levels of minerals, trace elements and specific vitamins, only body weight is considered. As horses may vary in their activity, resulting in different energy and nutrients requirements, different classes are made that represent intensity of activity in terms of type of activity (e.g. walking, trotting, jumping), duration, and 
the speed of locomotion in case of trotting and galloping. For each class of activity, additional amounts of energy and specific nutrients are available.

The additional energy, protein and mineral requirements of gestating horses and ponies depend on their body weight and month of gestation. For trace elements and vitamin A, the additional requirements only depend on body weight of the mare. Similarly, body weight and time in lactation determines the additional energy, protein and mineral requirements of horses and ponies. Body weight determines the additional requirements for trace elements and vitamins. The requirements of growing horses and ponies during the first 36 months of life have been established for three expected adult weight classes.

\subsubsection{Tolerances in animals}

Apart from differences in metabolic capacities of animals that underlie their nutrient requirements, the metabolic capacity also underlies their tolerance to specific compounds. These compounds can be nutrients like certain vitamins, minerals or trace elements but also non-nutrient compounds. Some food leftovers could consist out of high dioxin levels (due to burned cookies, bread etc.), which could be transferred into i.e. meat and eggs. Besides the compounds due to processing, also complete feedstuffs could affect animals. For example, grapes, raisins, chocolate, garlic and onions contain compounds that are toxic in dogs and cats. It goes beyond the scope of this report to provide an overview of maximum tolerance levels for nutrients. Food leftovers and co-products are not always known to animals, due to their function for human consumption. Thus, when considering food leftovers and co-products as feedstuffs for animals it is of importance to understand whether the animals have the metabolic capacity to tolerate these. Furthermore, animals might also not tolerate foods with off-flavour and completely reject the diet fed.

\subsubsection{Summarising notes on dietary requirements}

Based on the basic information provided above it becomes clear that animal species differ in their requirements for energy and nutrients for maintenance processes and that production of meat, milk or eggs requires additional energy and nutrients. Furthermore, physical properties of diets are important to support proper gastrointestinal functioning. Lastly, compounds present at levels beyond an animal's metabolic coping capacity and compounds causing off-flavours need to be avoided. Feeding guidelines that take these aspects into account are available for animals at maintenance and in production. These guidelines provide a basis to compose or evaluate diets composed out of food leftovers and co-products and estimate animal production rates.

\subsection{Animal diets and feedstuffs}

\subsubsection{Feedstuffs}

Knowledge on the nutrient composition of ingredients, also named feedstuffs, the bioavailability of the nutrients, and on the nutrient requirements of the animal makes it possible to formulate a diet that is optimal for the performance of the target animal with minimal losses to the environment. As indicated above, the CVB has evaluated the nutritional value of feedstuffs for production animals in terms of chemical (nutrient) composition and for some components also data on the bioavailability. The bioavailability is often estimated in studies that quantified the degree of enzymatic or microbial digestion of the feedstuff or diet containing the feedstuff in the target animal. Based on these values, estimates of energy value of the feedstuff can be calculated using species specific formulae. Vitamins and minerals are typically added to the diets in the form of a so-called 'premix'. Specific premix formulations exist depending on the requirements of the target animal to be fed as well as the number of vitamins and minerals already present in the feedstuffs used in the formulated diet.

For livestock species, a large variety of feedstuffs has been characterised, with each feedstuff having its own specific feeding value for each category of animal species. It should be realized that not only single feedstuffs, but the complete composition of the diet is important. The properties of single feedstuffs could change or affect other feedstuffs within a diet and the sum of properties is what is offered to the animals. Databases such as the one of the CVB that list these properties of feedstuffs are freely available and form the basis of the formulation of diets for livestock to attain specific production levels. These 
tables are routinely used by farmers and feed producing companies. The formulation of diets is custommade per farm by the feed producing company, taking specific characteristics or problems (i.e. health status) into account.

\subsubsection{Diets}

Ruminants (cows, sheep, goats) are normally fed with fibre-rich roughages, such as grass, maize and alfalfa, and additionally get 'concentrates', which are feed pellets that are relatively high in starch and protein. Ruminants are normally fed with grass, grass silage and/or maize silage, added with concentrate. Nowadays, dairy cows are fed with maize silage, because of the high energy content of the maize starch. Also, the concentrate normally contains starch and protein. Without these high energy components dairy cattle will not meet their high requirements. In nature and when not producing, ruminants can survive on only grass, hay or grass silage, supplemented with vitamins and minerals.

Due to their incapability to digest high amounts of fibres, pigs and poultry are normally fed with only concentrates, either in pelleted, crumble, mash or liquid form. Concentrates can be composed of many different feed ingredients. Major starch-rich ingredients are maize, wheat and tapioca, and protein-rich ingredients include soybean, rapeseed and palm kernel meals. All kind of other products are used in concentrates, depending on the availability and price. Insects are considered as livestock species and as such should be fed with food- or feed-grade material (Bosch et al., 2019). Dogs and cats are typically fed dry extruded or wet retorted foods for which the proteins originate from livestock or fish and starches from cereal grains and tubers.

Table 2 illustrates a typical nutrient composition of diets for different animal species in The Netherlands. Profound differences can be noted, which relate to the digestive capacities and (metabolic) nutrient requirements of the animal species. For example, a dairy cow is capable of utilising a high fibre diet, laying hens require substantial amounts of calcium for eggshell formation and high protein diets of cats in part relate to their high level of metabolic amino acid catabolism. Diet formulations also include safety margins to take animal variation in digestive and metabolic efficiencies and variation in diet quality into account. The latter relates to both biological variations in feedstuffs, due to e.g. region of origin, maturity (harvest date) as well as beneficial and detrimental effects of processing on nutritional quality. These safety margins go with economic costs and sometimes with environmental costs. Production animals are typically fed very close to their requirements whereas non-production animals are commonly fed (more expensive) diets that should prevent any case of deficiency. Note that there can also be substantial variation in animal production systems and practices that impact how and what animals are fed. For example, growing pigs may be fed only dry pelleted feeds but at some pig farms wet feeds are used. Dog owners may opt for dry kibbled foods because of price and convenience whereas others want to feed 'evolutionary'-based raw meat-based foods with protein levels four times above the minimal requirement. For insects, there are no standard feeds reported in the literature. 
Table 2 Typical nutrient composition (\% of DM) of diets for different animal species in the Netherlands.

\begin{tabular}{|c|c|c|c|c|c|c|}
\hline Nutrient & $\begin{array}{l}\text { Dairy } \\
\text { cow }^{1}\end{array}$ & $\begin{array}{l}\text { Growing } \\
\text { pig }^{2}\end{array}$ & $\begin{array}{l}\text { Laying } \\
\text { hen }{ }^{3}\end{array}$ & Broiler $^{4}$ & $\operatorname{Dog}^{5}$ & Cat $^{6}$ \\
\hline Organic matter & $90.5-92.1$ & 94.5 & 85.7 & 94.8 & 91.8 & 92.6 \\
\hline Protein & $14.3-17.5$ & 18.8 & 16.9 & 21.9 & 30.1 & 36.9 \\
\hline Fat & $3.0-3.4$ & 5.4 & 8.0 & 10.0 & 15.4 & 14.4 \\
\hline Starch & $6.2-16.4$ & 44.2 & 39.9 & 40.9 & 30.2 & 24.6 \\
\hline Fibre $^{7}$ & $34.3-40.3$ & 26.1 & 20.9 & 22.0 & 16.1 & 16.7 \\
\hline Minerals & $8.1-9.7$ & 5.5 & 14.3 & 5.2 & 8.2 & 7.4 \\
\hline
\end{tabular}

${ }^{1}$ Abrahamse et al. (2007)

${ }^{2}$ Grower phase (20 to $50 \mathrm{~kg}$ body weight) fed a diet composed out of $88 \%$ dry matter (Bikker, personal communication).

${ }^{3}$ Production phase $>18$ weeks, assuming $89 \%$ dry matter (Bikker, personal communication).

${ }^{4}$ Grower/finisher phase (11 to $35 \mathrm{~d}$ of age) fed a diet composed out of $88 \%$ dry matter (Bikker, personal communication).

${ }^{5}$ Average of five grain-based commercial dry extruded foods (Alvarenga and Aldrich, 2020).

${ }^{6}$ Average of five grain-based commercial dry extruded foods (Alvarenga and Aldrich, 2020).

${ }^{7}$ For dairy cow neutral detergent fibre is presented and for other species non-starch polysaccharide levels are presented. 


\section{Upcycling in animal nutrition}

\subsection{Upcycling co-products and food leftovers}

The upcycling of food and biofuel co-products, as well as food leftovers as animal feed, is a favourable option in circular systems (Salemdeeb, Zu Ermgassen, Kim, Balmford, \& Al-Tabbaa, 2017; Van Zanten et al., 2019). The feed of livestock around the globe consists already for $86 \%$ of dry matter made of materials that are not eaten by humans (Mottet et al., 2017). This $86 \%$ consists mostly out of grassland, which is unsuitable for the production of other crops. The remaining $14 \%$ are grains for animal feed, which are unsuitable for human consumption. However, this land could be used to produce food directly suitable for human consumption. Furthermore, the CVB database includes about 200 different co- and by products from the food and biofuel industries. Well known co-products used in livestock diets are beet pulp, breweries grains and potato pulp. A food leftover stream already used in animal feeding is the non-sold food products from i.e. supermarkets. These products are collected, processed and sold as feedstuffs (e.g. see https://www.nijsen-granico.nl/duurzaam-voeren/ from Nijssen/Granico in Veulen, The Netherlands). In Europe, only $3 \%$ of the food leftovers is upcycled as animal feed whereas using swill as pig feed could reduce the land use for EU pork production by one fifth (Zu Ermgassen, Phalan, Green, \& Balmford, 2016). Swill, being kitchen left-overs from e.g. restaurant or canteens, has a high feed value especially for pigs and poultry (Michael L. Westendorf, 2000) but can also be used to grow insects (e.g. Cheng, Chiu, \& Lo, 2017; Nguyen, Tomberlin, \& Vanlaerhoven, 2013). However, legislation prohibits using various streams of food leftovers, such as swill, in feed due to European food safety measures (Table 3). Especially food leftovers containing animal (by-)products could potentially transmit infectious diseases such as foot-and-mouth disease, Bovine Spongiform Encephalopathy, or African Swine Fever. The large 2001 foot-and-mouth disease outbreak in the UK and other European countries is believed to be caused by a pig famer illegally feeding his pigs with uncooked food leftovers (UK House of Commons report, 2002). On the other hand, Japan and South Korea collect and heat-treat swill and upcycle in total $36 \%$ and $43 \%$ of the food leftovers (Sugiura, Yamatani, Watahara, \& Onodera, 2009; Zu Ermgassen et al., 2016). Before swill can be legalized as feedstuff in Europe, confidence and support of the public, industry and policy makers are required and collection should be done as a separate stream to ensure safety and quality of the swill (Salemdeeb et al., 2017). Unsold products from agricultural auctions or wholesale trade can potentially be used as valuable feedstuff, as well as the small amounts of vegetables and fruits with aberrant shapes that are not sold. Lastly, co-products with a high lignin content, such as straw and wood pruning's, can be treated with chemicals or fungi to turn it into valuable feed for ruminants. 


\begin{tabular}{|c|c|c|c|}
\hline Group & Description & $\begin{array}{l}\text { Legal } \\
\text { status }\end{array}$ & Legal justification \\
\hline A & $\begin{array}{l}\text { Animal feed materials according to the EU } \\
\text { catalogue of feed materials and authorized as } \\
\text { feed for food producing animals. }\end{array}$ & $\checkmark$ & Regulation (EU) No 68/2013 \\
\hline \multirow[t]{2}{*}{ B1 } & $\begin{array}{l}\text { Food produced for human consumption, but } \\
\text { which is no longer intended for human } \\
\text { consumption for reasons such as expired use-by } \\
\text { date or due to problems of manufacturing or } \\
\text { packaging defects. Excluding meat and fish } \\
\text { (processed animal proteins, PAPs). }\end{array}$ & $\checkmark$ & $\begin{array}{l}\text { Former foodstuffs of vegetable origin: } \\
\text { - } \quad \text { Regulation (EU) No } 68 / 2013 \\
\text { Permitted former foodstuffs of Animal } \\
\text { origin (non-PAPs): } \\
\text { - } \quad \text { Regulation (EU) No } 142 / 2011 \text {, } \\
\quad \text { Annex X, Chapter II, Section } 10\end{array}$ \\
\hline & $\begin{array}{l}\text { Meat and fish produced for human consumption, } \\
\text { but which is no longer intended for human }\end{array}$ & & $\begin{array}{l}\text { Regulation (EC) No 999/2001, } \\
\text { Article 7(2) }\end{array}$ \\
\hline \multirow[t]{2}{*}{ B2 } & $\begin{array}{l}\text { consumption for reasons such as expired use-by } \\
\text { date or due to problems of manufacturing or }\end{array}$ & \multirow[t]{2}{*}{$\mathrm{X}$} & $\begin{array}{l}\text { Regulation (EU) No 142/2011, } \\
\text { Annex X, Chapter II, Section } 10\end{array}$ \\
\hline & packaging defects. & & 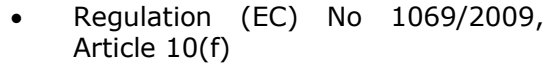 \\
\hline \multirow{2}{*}{$\mathrm{C}$} & $\begin{array}{l}\text { By-products from slaughterhouses (hides, hair, } \\
\text { feathers, bones etc.) that do not enter the food }\end{array}$ & \multirow{2}{*}{$\mathrm{X}$} & $\begin{array}{l}\text { Regulation (EC) No 999/2001, } \\
\text { Article 7(2) }\end{array}$ \\
\hline & $\begin{array}{l}\text { chain but originate from animals fit for human } \\
\text { consumption. }\end{array}$ & & $\begin{array}{l}\text { Regulation (EC) No 1069/2009, } \\
\text { Article 10(b) }\end{array}$ \\
\hline D & $\begin{array}{l}\text { Food waste from food for human consumption of } \\
\text { both animal and non-animal origin from } \\
\text { restaurants, catering and households. }\end{array}$ & $\mathrm{X}$ & $\begin{array}{l}\text { - Regulation (EC) No 1069/2009, } \\
\text { Article 11(1)b }\end{array}$ \\
\hline E & Animal manure and intestinal content. & $X$ & $\begin{array}{l}\text { - } \begin{array}{l}\text { Regulation (EC) No 1069/2009, } \\
\text { Article 9(a) }\end{array}\end{array}$ \\
\hline $\mathrm{F}$ & $\begin{array}{l}\text { Other types of organic waste of vegetable nature } \\
\text { such as gardening and forest material. }\end{array}$ & $\checkmark / x$ & $\begin{array}{ll}\text { - } & \text { Regulation (EC) No 767/2009, } \\
& \text { Annex III } \\
\text { - } & \text { Regulation (EC) No 68/2013 } \\
\text { - } & \text { Directive 2008/98/EC }\end{array}$ \\
\hline G & Human manure and sewage sludge. & $\mathrm{X}$ & $\begin{array}{ll}\text { - } & \text { Regulation (EC) No 767/2009, } \\
& \text { Article } 6 \\
\text { - } & \text { Directive 91/271/EEC } \\
\text { - } & \text { Directive 86/278/EEC } \\
\end{array}$ \\
\hline
\end{tabular}

\subsection{Animals in circular food systems in the Amsterdam Metropolitan Area}

The Amsterdam Metropolitan Area (AMA) has ambitious plans concerning circularity. By 2030 the city of Amsterdam wants to use $50 \%$ less new raw materials and by 2050 they want to be completely circular. To reach $100 \%$ circularity, one of the pillars is food and organic waste: reduce food leftovers and find solutions for restaurant/kitchen left-overs and garden waste (Gemeente Amsterdam \& Circle Economy, 2020). Recently, a lot of local initiatives are studying or trying to separate organic waste from households, constructing a "food forest", produce food locally and to educate the inhabitants (Gemeente Amsterdam, 2020). These projects can be a solid basis for safe and valuable collection of organic waste. None of the initiatives, however, mentioned the use of animals despite that feeding animals with food co-products and food leftovers is part of the food hierarchy. Therefore, we can only speculate on the possibilities of using co-products and food leftovers in AMA. Furthermore, this stresses the importance of performing evaluations and local studies in which animals are fed with diets based on organic waste. In the AMA various co-products and food leftovers are generated that can potentially be used to feed animals. A variety of animals is already living in the Amsterdam Metropolitan Area; from production animals, such as ruminants, pigs, poultry and fish to non-productive animals, such as companion and zoo animals. The CbD project is researching the potential and size of the (possible) circular agri-food system in order to develop relevant solutions. For livestock and aquaculture farms, a large part of the feed is already based on co-products, though the origin could be from various parts of the globe instead from the AMA. Households or small communities may consider to feed own food leftovers to animals at nearby farms, which in return provide the participants meat, milk or eggs. This could be organized in collaboration with the AMA, separate municipalities, (local) animal feed manufacturers, or waste collection services/processors. Furthermore, manure can be used to fertilise soil used to produce food crops. Manure could also be used to grow detrivorous insects, like black soldier fly larvae, which in turn can be used as a feedstuff in diets for pigs, chickens or fish or for direct human consumption. There is potential to make the agri-food systems in the AMA more circular by using animals as upcyclers. This 
requires, however, a framework in which co-products and food leftovers are evaluated for suitability as a feedstuff for specific animal species. Ideally, this also includes the possibility to quantify potential animal production and replacement of non-AMA feedstuffs. Such framework has in part been developed and described by van Hal et al. (2019).

\subsection{Previous circular systems}

\subsubsection{Production animals}

Feeding co-products or food leftovers to production animals has been common practice throughout their domestication history. Several studies have researched the effects of feeding co-products or food leftovers on production animals. In this paragraph a few studies are highlighted.

\section{Pigs}

Pigs are great waste converters, since they are omnivorous and due to their capacity to consume wet feed. Within pig diets organic waste could partially be included. Esteban, Garcia, Ramos, and Marquez (2007) evaluated fruit, vegetable and fish leftovers as feedstuffs for pig diets. Because of the higher fat and fibre content of these sources, around $20 \%$ of the food leftovers could be used to formulate a diet that meets a commercial diet. Food plate leftovers can be a reasonable source of nutrients for growing pigs, though variability among sources as well as high sodium and fat require attention

(M.L. Westendorf, Schuler, \& Zirkle, 1999). Salemdeeb et al. (2017) evaluated the environmental and health impacts of converting municipal food leftovers into pig feed. They conducted a hybrid life cycle assessment (LCA) to compare the food leftovers offered as dry or wet pig feed, or as composted or anaerobic digested pig feed. According to their results, feeding food leftovers as wet pig feed had the highest ranking, followed by dry feed, anaerobic digestion and composting. Especially substituting conventional animal feed for wet or dry feed, with all the substantial emission that processing and transportation of conventional feed withholds, made these two categories the most impactful. The fossil fuel used for dehydration which is necessary to produce the dry feed, was the biggest difference between the wet and dry scores.

\section{Ruminants}

Though ruminants are commonly fed by-products from the food and biofuel industries, not many studies used ruminants to feed food leftover products. However, due to their gut morphology several vegetable and fruit leftover sources could be relevant. Angulo et al. (2012) tested the inclusion of 0, 6, 8, 12 and $18 \%$ of fruit and vegetable leftovers from a market place in the diets of lactating dairy cows. They did not find any effects on the milk production, but did find an increase on cis-9,trans-11 CLA and a-linolenic acid content in the milk, which actually improves the milk quality. Furthermore, Márquez, Diánez, and Camacho (2011) evaluated vegetable leftovers from greenhouses as successful to feed sheep and goats. The authors do stress that these feedstuffs need to be traceable for a safe use. Ngu and Ledin (2005) studied the effects of feeding cabbage and cauliflower leftovers to goats. Due to a low dry matter, they found lower feed intake when goats where fed cabbage. Furthermore, they saw an increase in feed intake and body weight gain when they were fed cauliflower compared to the control diet. Leftover products with a high lignin content, such as straw and wood pruning's, can be treated with chemicals or fungi to turn it into valuable feed for ruminants (Van Kuijk, Sonnenberg, Baars, Hendriks, \& Cone, 2015).

Fish

Farmed fish nutrition also has a high potential for the use of food leftovers. Nasser, Abiad, Babikian, Monzer, and Saoud (2018) evaluated the use of postconsumer food leftovers partially substituting commercial feed in tilapia aquaculture. They performed 2 experiments: within the first experiment ascending daily meals ( 4 meals a day) were substituted by food leftovers and in the second experiment ascending days ( 7 day feed regime) were substituted by food leftovers. The plate food leftovers were collected from two local restaurants, inspected for nonorganic materials, and subsequently ground and dried to a moisture content of $6 \%$. The first experiment showed that the replacement of 1 meal a day (25\%) did not affect the performance of the fish. Similar results were found in the second experiment, where between one and two days a week replacement did not affect the performance. However, the authors discuss the possible negative effects on growth due to a lower protein content and negative 
effects on digestibility due to a high cellulose content. Furthermore they stress that using food leftovers in commercial settings with more restaurants as sources is logistically challenging (i.e. collection, storage, processing and spoilage reduction).

\section{Poultry}

Using food leftovers or co-products is not common in modern poultry farming in Europe. The wild ancestors of poultry, the red jungle fowl, has a varied diet of insects, seeds, plants and fruits. However, farmed poultry is mostly fed with grains and other plant-based feedstuffs. Especially wet feedstuffs are avoided due to the digestive capacity of birds.

A few examples in poultry can be mentioned. An older study by Rehman, Ali, Khan, \& Shah (2006) replaced dietary rice polishing by fruit and vegetable leftovers in laying hens diets. Their results suggested that carrots, orange leftovers and mango peels did not affect egg production but could increase egg weight. More recently, a Dutch laying hen farm launched a circular system to produce eggs. This so-called "Kipster" farm feeds their laying hens on feed produced by a feeding company that uses the surplus and leftovers of bakeries only.

\section{Insects}

In nature, various insect species are specialised in converting organic waste, such as dead plant materials, dead animals and animal faeces. Insects are energy-efficient because of their poikilothermic nature. Relative to conventional livestock ruminants, pigs, and poultry, insects have a high proportion of edible weight. Insects can therefore achieve higher feed conversion efficiencies than conventional livestock species. Insects have been proposed to increase both the productivity and the efficiency of the food chain (Van Huis et al., 2013). Research on using insects to convert residual organic streams is rapidly evolving. In particular black soldier fly larvae (Hermetia illucens, BSFL) receive considerable interest as these have the ability to upcycle various residual organic resources (see Bosch et al., 2019) into protein-rich biomass fit as feed ingredients for pigs, chickens and fish (e.g. Bondari \& Sheppard, 1981; De Marco et al., 2015; Newton, Booram, Barker, \& Hale, 1977). Residual streams investigated in this species included a spectrum of streams from food leftovers to dairy cattle manure. Resources may differ greatly in nutritional quality and, therefore, in their impact on larval development time, biomass yield and quality, associated emissions and residual matter (frass and exuvia) (Bosch et al., 2019). According to current European Union regulations, organic products that can be fed to insects are the same as those that can be fed to conventional livestock species. Therefore, insects may compete with livestock for resources (Bosch et al., 2019). To make the food system more productive, it will be interesting to see if other resources, such as manure, can be used to produce insects in a safe and economic way.

\subsubsection{Non-production animals}

\section{Dogs and cats}

Humans have shared their foods and leftovers with dogs and cats for thousands of years. In particular for dogs, which are considered to have a more adaptive digestive physiology and metabolism than cats, these leftovers could be a larger part of their diet, whereas cats would have been still very much dependent on small rodents and birds (Hendriks \& Bosch, 2018). Still a proportion of the pet dog and cat populations are being fed table scraps, though this should be limited in amounts to prevent unbalanced diets that result in nutrition-related health problems. The ingredients used to compose commercial pet food products originate from crops, aquaculture, livestock and human foods. The protein sources are mainly co-products from the rendering industry. For dry extruded foods, meat and byproduct meals of poultry, beef, pig, lamb and fish are most commonly used. For wet retorted foods, proteins mainly originate from fresh and/or frozen meats and other animal tissues. Some of these latter products are also fit for human consumption, but their use as such is culture dependent. The foods should be (microbially) safe for humans with compromised immune systems as owners handle the foods, children may even eat the food, and pets may infect owners with the microbes they carry. It is also important to stress that the owners select the food products for their pets and as such their beliefs and perceptions of a fair and quality product determine what is being developed. Societal concerns about the planet and the desire to consume more locally produced products are being translated in new products. For example, Shameless Pets produce snacks from fruit, vegetable and dairy leftovers. This example illustrates that there is potential to upcycle food leftovers into pet food products. Apart from 
the nutritional evaluation of conventional food by-products, such food leftovers have not been studied for nutritional quality and safety. 


\section{$4 \quad$ Concluding remarks}

The aim of this report was to describe the role of animals in circular agri-food systems. It is clear that animals can be fed with co-products or food leftovers and as such could potentially contribute to making agri-food systems more circular. Production as well as non-production animals are commonly fed with a wide range of co-products from the agri-food system, which fall within the EU feed regulation. Various forms of food leftovers can also be interesting sources of nutrients for animals, but limited research has been performed. The chemical and physical characteristics of these potential feedstuffs will impact the nutritional value for a given animal species as well as how it should be incorporated in a diet or fed to have the most efficient strategy of upcycling. The volumes and compositions of the co-products or food leftovers will vary among regions and seasons and it is essential to collect data to enable an assessment of their potential as animal feedstuff and to estimate the quantities of conventional ingredients that can be replaced and spared. Furthermore, the scale at which these are collected and potentially be fed might differ greatly; from family kitchen leftovers fed to backyard animals to more advanced systems of collection and dedicated farms where animals are fed balanced diets containing the processed food leftovers. In the case of production animals, such factors have a profound influence on the amount and quality of the animal-derived products. Furthermore, production potential of specific breeds requires consideration as the highly productive breeds fed conventional diets might perform less well than other breeds when fed a diet fully based on more fibrous co-products and/or specific types of food leftovers. In any case, feed and food safety should be considered, which was not addressed in the present brief introductory report. In the next phase of the project, it will be important to work on different cases and illustrate in different scenarios how decisions to feed co-products or food leftovers to specific animals will or will not impact the circularity of the agri-food system. 


\section{Literature}

Abrahamse, P.A., Dijkstra, J., Tamminga, S. (2007) De invloed van de samenstelling van het winterrantsoen op het voeropnamepatroon van melkkoeien in verschillende lactatiestadia en het effect hiervan op penskarakteristieken. Report Wageningen University. https://edepot.wur.nl/17078

Angulo, J., Mahecha, L., Yepes, S. A., Yepes, A. M., Bustamante, G., Jaramillo, H., Gallo, J. (2012). Nutritional evaluation of fruit and vegetable waste as feedstuff for diets of lactating Holstein cows. Journal of Environmental Management, 95, S210-214. doi:10.1016/j.jenvman.2011.06.050

Bondari, K., \& Sheppard, D. C. (1981). Soldier fly larvae as feed in commercial fish production. Aquaculture, 24(C), 103-109. doi:10.1016/0044-8486(81)90047-8

Bosch, G., Van Zanten, H. H. E., Zamprogna, A., Veenenbos, M., Meijer, N. P., Van der Fels-Klerx, H. J., \& Loon, J. J. A. (2019). Conversion of organic resources by black soldier fly larvae: Legislation, efficiency and environmental impact. Journal of Cleaner Production, 222, 355-363.

Corsato Alvarenga, I., \& Aldrich, C. G. (2020). Starch characterization of commercial extruded dry pet foods. Translational Animal Science, 4(2), txaa018. doi.org/10.1093/tas/txaa018

Cheng, J. Y. K., Chiu, S. L. H., \& Lo, I. M. C. (2017). Effects of moisture content of food waste on residue separation, larval growth and larval survival in black soldier fly bioconversion. Waste Management, 67, 315-323. doi:10.1016/j.wasman.2017.05.046

CVB (2020). Tabellenboek Voeding Varkens 2020: Voedernormen Varkens en voederwaarden voedermiddelen voor Varkens. Den Haag: Federatie Nederlandse Diervoederketen 2020.

CVB(2018). Tabellenboek Veevoeding 2018: Voedernormen Pluimvee en voederwaarden voedermiddelen voor Pluimvee. Den Haag: Federatie Nederlandse Diervoederketen 2018.

CVB (2016). Tabellenboek Veevoeding 2016: Voedernormen Rundvee, Schapen, Geiten en voederwaarden voedermiddelen voor Herkauwers. Den Haag: CVB Productschap Diervoeder. Federatie Nederlandse Diervoederketen 2018.

CVB (2016). Tabellenboek Veevoeding 2016: Voedernormen Paarden en pony's en voederwaarden voedermiddelen voor Paarden en Pony's. Den Haag: CVB Productschap Diervoeder. Federatie Nederlandse Diervoederketen 2018.

CVB (2016). Tabellenboek Veevoeding 2016: Voedernormen Konijnen en voederwaarden voedermiddelen voor Konijnen. Den Haag: CVB Productschap Diervoeder. Federatie Nederlandse Diervoederketen 2018.

CVB (2011). CVB Veevoedertabel 2011: chemische samenstellingen en nutritionele waarden van voedermiddelen [CVB Feedstuff table 2011: chemical compositions and nutritional values of feedstuffs]. Den Haag: CVB Productschap Diervoeder.

De Marco, M., Martínez, S., Hernandez, F., Madrid, J., Gai, F., Rotolo, L., . . Schiavone, A. (2015). Nutritional value of two insect larval meals (Tenebrio molitor and Hermetia illucens) for broiler chickens: Apparent nutrient digestibility, apparent ileal amino acid digestibility and apparent metabolizable energy. Animal Feed Science and Technology, 209, 211-218. doi:10.1016/j.anifeedsci.2015.08.006

Esteban, M. B., Garcia, A. J., Ramos, P., \& Marquez, M. C. (2007). Evaluation of fruit-vegetable and fish wastes as alternative feedstuffs in pig diets. Waste Manag, 27(2), 193-200. doi:10.1016/j.wasman.2006.01.004

Gemeente Amsterdam. (2020). Innovatie en Uitvoeringsprogramma. Retrieved from Amsterdam, The Netherlands:

Gemeente Amsterdam, \& Circle Economy. (2020). Strategie Amsterdam Circulair 2020-2025. In. Amsterdam, The Netherlands: Gemeente Amsterdam.

Hendriks, W. H., \& Bosch, G. (2018). Aspects of comparative animal nutrition and the evaluation of pet foods. In P. J. Moughan \& W. H. Hendriks (Eds.), Feed evaluation science (pp. 491-524). Wageningen, The Netherlands: Wageningen Academic Publishers.

Márquez, M. A., Diánez, F., \& Camacho, F. (2011). The use of vegetable subproducts from greenhouses (VSG) for animal feed In the Poniente region of Almería. Renewable Agriculture and Food Systems, 26(1), 4-12.

Mottet, A., de Haan, C., Falcucci, A., Tempio, G., Opio, C., \& Gerber, P. (2017). Livestock: On our plates or eating at our table? A new analysis of the feed/food debate. Global Food Security, 14, 1-8. doi:10.1016/j.gfs.2017.01.001

Nasser, N., Abiad, M. G., Babikian, J., Monzer, S., \& Saoud, I. P. (2018). Using restaurant food waste as feed for Nile tilapia production. Aquaculture Research, 49(9), 3142-3150. doi:10.1111/are.13777 
Newton, G. L., Booram, C. V., Barker, R. W., \& Hale, O. M. (1977). Dried Hermetia Illucens larvae meal as a supplement for swine. Journal of Animal Science, 44, 395-400.

Ngu, N. T., \& Ledin, I. (2005). Effects of Feeding Wastes from Brassica Species on Growth of Goats and Pesticide/Insecticide Residues in Goat Meat. Asian-Australian Journal of Animal Sciences, 18, 197-202.

Nguyen, T. T. X., Tomberlin, J. K., \& Vanlaerhoven, S. (2013). Influence of resources on Hermetia illucens (diptera: Stratiomyidae) larval development. Journal of Medical Entomology, 50(4), 898-906. doi: $10.1603 / \mathrm{me} 12260$

Rehman, Z. U., Ali, S., Khan, A. D., \& Shah, F. H. (2006). Utilisation of Fruit and Vegetable Wastes in Layers' Diet. Journal of the Science of Food and Agriculture, 65, 381-383.

Salemdeeb, R., Zu Ermgassen, E. K., Kim, M. H., Balmford, A., \& Al-Tabbaa, A. (2017). Environmental and health impacts of using food waste as animal feed: a comparative analysis of food waste management options. J Clean Prod, 140, 871-880. doi:10.1016/j.jclepro.2016.05.049

Steffen, W., Richardson, K., Rockström, J., Cornell, S. E., Fetzer, I., Bennett, E. M., . . Sörlin, S. (2015). Planetary boundaries: Guiding human development on a changing planet. Science, 347(6223), 1259855. doi: $10.1126 /$ science. 1259855

Stevens, E. C., \& Hume, I. D. (1998). Contributions of microbes in vertebrate gastrointestinal tract to production and conservation of nutrients. Physiological Reviews, 78(2), 393-427.

Sugiura, K., Yamatani, S., Watahara, M., \& Onodera, T. (2009). Ecofeed, animal feed produced from recycled food waste. Veterinaria Italiana, 45, 397-404.

Swanson, K. S., Carter, R. A., Yount, T. P., Aretz, J., \& Buff, P. R. (2013). Nutritional sustainability of pet foods. Advances in Nutrition, 4, 141-150.

UK House of Commons (2002). The 2001 outbreak of food and mouth disease. Report by the comptroller and auditor general. London, UK.

van Hal, O., de Boer, I. J. M., Muller, A., de Vries, S., Erb, K. H., Schader, C., . . van Zanten, H. H. E. (2019). Upcycling food leftovers and grass resources through livestock: Impact of livestock system and productivity. Journal of Cleaner Production, 219, 485-496. doi:10.1016/j.jclepro.2019.01.329

Van Huis, A., Van Itterbeeck, J., Klunder, H., Mertens, E., Halloran, A., Muir, G., \& Vantomme, P. (2013). Edible insects: future prospects for food and feed security. Rome, Italy: Food and Agriculture Organization of the United Nations (FAO).

Van Kuijk, S. J. A., Sonnenberg, A. S. M., Baars, J. J. P., Hendriks, W. H., \& Cone, J. W. (2015). Fungal treated lignocellulosic biomass as ruminant feed ingredient: A review. Biotechnology Advances, 33(1), 191-202. doi: $10.1016 /$ j.biotechadv.2014.10.014

Van Zanten, H. H. E., Van Ittersum, M. K., \& De Boer, I. J. M. (2019). The role of farm animals in a circular food system. Global Food Security, 21, 18-22. doi:10.1016/j.gfs.2019.06.003

Westendorf, M. L. (Ed.) (2000). Food Waste to Animal Feed (1st ed.). Ames: Iowa State University Press.

Westendorf, M. L., Schuler, T., \& Zirkle, E. W. (1999). Nutritional quality of recycled food plate waste in diets fed to swine. The Professional Animal Scientist, 15, 106-111.

Zu Ermgassen, E. K., Phalan, B., Green, R. E., \& Balmford, A. (2016). Reducing the land use of EU pork production: where there's swill, there's a way. Food Policy, 58, 35-48. doi:10.1016/j.foodpol.2015.11.001 


\section{Appendix 1}

Requirements dairy cattle

The energy requirements of dairy cattle is expressed in the so-called feed unit milk (VEM = voedereenheid melk). The amount of VEM per day for maintenance and milk production is:

$$
\begin{aligned}
& \text { VEM }=\left(42.4 \times B^{0.75}+442 \times C M\right) \times\{1+(C M-15) \times 0.00165\} \\
& B W=\text { body weight in } \mathrm{kg} \\
& \mathrm{CM}=\text { corrected milk }(\mathrm{kg} / \text { day }) \text { for fat }(\mathrm{FCM}) \text { or corrected for fat and protein (FPCM) }
\end{aligned}
$$

For a dairy cow of $650 \mathrm{~kg}$ the VEM requirement per day can be estimated with:

$$
\operatorname{VEM}=5323+440 \times \mathrm{CM}+0.73 \times \mathrm{CM}^{2}
$$

The requirements on intestinal digestible protein (DVE $=$ darm verteerbaar eiwit) is for maintenance:

$$
\operatorname{DVE}_{\text {maintenace }}(\mathrm{g} / \text { day })=\left(2.75 \times \mathrm{BW}^{0.5}+0.2 \times \mathrm{BW}^{0.6}\right) / 0.67
$$

Or more easy:

$\operatorname{DVE}_{\text {maintenace }}(\mathrm{g} /$ day $)=54+(0.1 \times \mathrm{BW})$

The DVE requirements for milk production can be estimated with:

$$
\begin{aligned}
& \mathrm{DVE}_{\text {milk production }}(\mathrm{g})=1.396 \times \mathrm{MP}+0.000195 \times \mathrm{MP}^{2} \\
& \mathrm{MP}=\text { milk protein production in } \mathrm{g} / \text { day }
\end{aligned}
$$

The equations are for average animals. As indicated above the values are also influenced by weight, parity, milk yield, milk composition etc. The exact requirements can be calculated with the help of the tables of CVB (CVB, 2010). The chemical composition of feed ingredients and feedstuffs should be analysed and the feed value (VEM, DVE) should be calculated, based on the chemical composition. Alternatively, CVB has average values for (almost) all feed ingredients and feedstuffs in their tables. These tables are routinely used farmers and feed producing companies.

\section{Requirements sheep}

The maintenance requirements for energy (VEM) and protein (DVE) for sheep is:

$$
\begin{aligned}
& \operatorname{VEM}\left(\text { per day) }=30 \times \mathrm{BW}^{0.75}\right. \\
& \operatorname{DVE}(\mathrm{g} / \text { day })=1.5 \times \mathrm{BW}^{0.75}
\end{aligned}
$$

As indicated for dairy cattle, also for sheep there are deviations from the equations. 


\section{Requirements goats}

The maintenance requirements for energy (VEM) for goats is:

$$
\begin{aligned}
& \text { VEM (per day) }=\left(36.4 \times \text { BW }^{0.75}+442 \times \text { FCM }\right) \times\{1+(\text { FCM }-2.75) \times 0.0009 \\
& \text { FCM = fat corrected milk }
\end{aligned}
$$

Or for a goat of $70 \mathrm{~kg}$ :

$$
\operatorname{VEM}(\text { per day })=879+443 \times \text { FCM }
$$

The DVE requirements for goats are calculated in the same way for dairy cattle. 


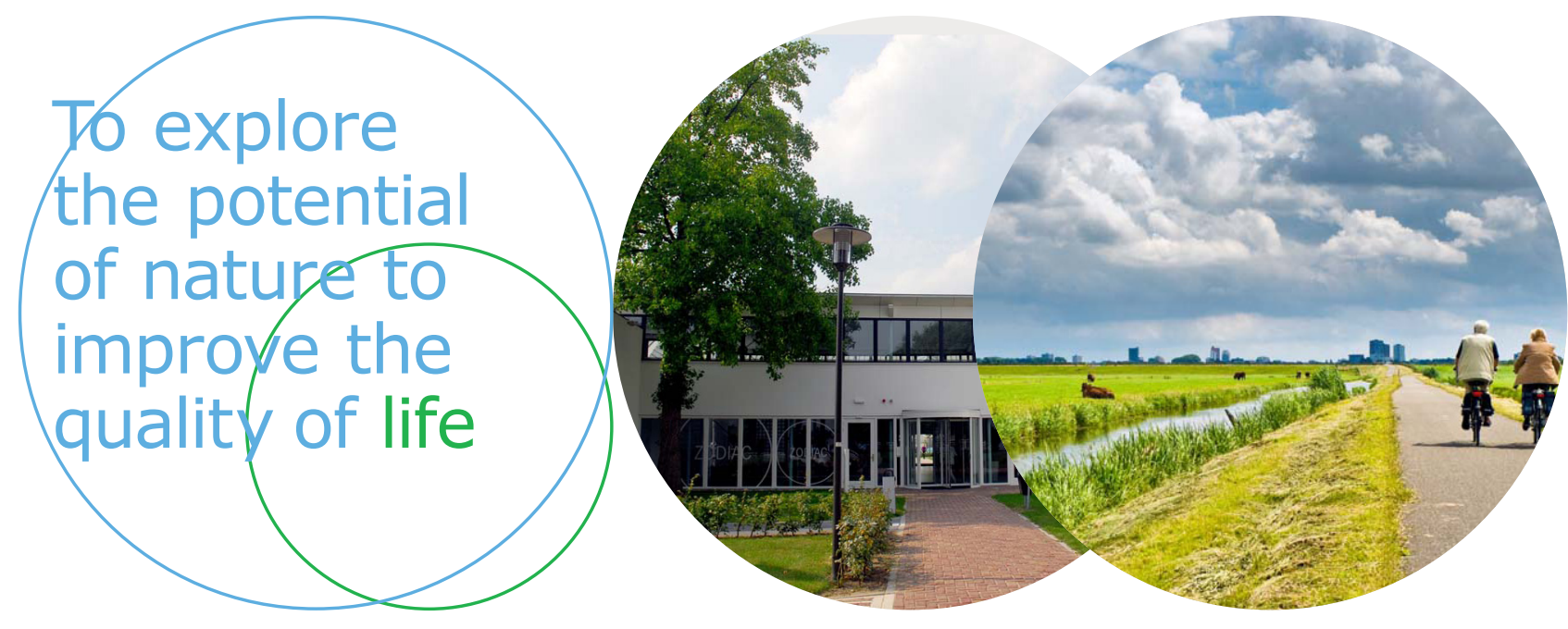

Wageningen Livestock Research P.O. Box 338

6700 AH Wageningen

The Netherlands

$\mathrm{T}+31(0) 317483953$

E info.livestockresearch@wur.nl

www.wur.nl/livestock-research

Wageningen Livestock Research creates science based solutions for a sustainable and profitable livestock sector. Together with our clients, we integrate scientific knowledge and practical experience to develop livestock concepts for future generations.

Wageningen Livestock Research is part of Wageningen University \& Research. Together we work on the mission: 'To explore the potential of nature to improve the quality of life'. A staff of 6,500 and 10,000 students from over 100 countries are working worldwide in the domain of healthy food and living environment for governments and the business community-at-large. The strength of Wageningen University \& Research lies in its ability to join the forces of specialised research institutes and the university. It also lies in the combined efforts of the various fields of natural and social sciences. This union of expertise leads to scientific breakthroughs that can quickly be put into practice and be incorporated into education. This is the Wageningen Approach. 